\title{
MENINGKATKAN PARTISIPASI MASYARAKAT DALAM PERENCANAAN PEMBANGUNAN GUNA MENGURANGI KEMISKINAN DI DESA JE’NETALLASA KABUPATEN GOWA
}

\author{
Ratna Ayu Damayanti ${ }^{1}$, Syarifuddin $^{2}$, Haerial $^{3}$ \\ ${ }^{1,2,3}$ Universitas Hasanuddin \\ Email: damayantiss@yahoo.co.id
}

\begin{abstract}
Je'netallasa Village, Pallangga Sub-district, Gowa Municipality has made the community as a subject of development, no longer as an object of development in accordance with the "bottom-up" model, and as a consequence the community has participated less in the process and supervision of village development. The purpose of this service is to eliminate doubts from villagers and encourage development effort by empowering the community. Encouraging community's inclusiveness in the form of "meaningful participation" will create active community's empowerment in the concept of village development as both planner and supervisor, as well as encouraging factors that influence community's participation. This service uses the participatory method, where the service provider and a community together find a solution to the problems faced by the community in order to participate in village's development. The result of this service is the need to establish a creative house as a center of community's creativity so that the community can engage with village's programs through synchronizing community's and village's programs on an ongoing basis.
\end{abstract}

Keywords: participation, village development, community, meaningful participation.

Abstrak. Desa Je'netallasa Kecamatan Pallangga Kabupaten Gowa telah menjadikan masyarakat sebagai subjek pembangunan bukan lagi sebagai objek pembangunan sesuai dengan model "bottom-up", dan konsekuensinya masyarakat kurang berpartisipasi dalam proses dan pengawasan pembangunan desa. Tujuan pengabdian ini adalah untuk menghilangkan keraguan masyarakat desa dan mendorong upaya pembangunan dengan melakukan pemberdayaan masyarakat. Mendorong inklusivitas masyarakat dalam bentuk "meaningful participation" akan menciptakan pemberdayaan aktif masyarakat dalam konsep pembangunan desa baik sebagai perencana maupun pengawas, serta mendorong faktor-faktor yang mempengaruhi partisipasi masyarakat itu. Pengabdian ini menggunakan metode berperan serta, dimana pelaku pengabdian dan masyarakat bersama-sama menemukan solusi dari masalah yang dihadapi masyarakat agar dapat berpartisipasi dalam pembangunan desa. Hasil dari pengabdian ini adalah perlunya membentuk rumah kreatif sebagai pusat kreativitas masyarakat sehingga masyarakat dapat terlibat dengan program-program desa melalui sinkronisasi program masyarakat dan desa secara berkelanjutan.

Kata Kunci: partisipasi, pembangunan desa, masyarakat, meaningful participation.

\section{PENDAHULUAN}

Pembangunan masyarakat desa merupakan gerakan pembangunan yang didasarkan pada keterlibatan dan swadaya gotong-royong masyarakat. Atas dasar itu maka kesadaran, peran serta, dan swadaya masyarakat perlu ditingkatkan agar partisipasi masyarakat dalam pembangunan dapat dirasakan sebagai suatu kewajiban bersama (Umboh, 2004). Makna partisipasi dan peran serta di sini bukan berarti bahwa masyarakat hanya berfungsi untuk memberikan dukungan dan keikutsertaan dalam proses pembangunan, tetapi juga menikmati hasil-hasil pembangunan itu sendiri. Dengan demikian, dapat tercipta sense of belonging dan sense of responsibility dalam proses pembangunan menuju tercapainya peningkatan kesejahteraan masyarakat secara keseluruhan.
Secara teoritis, tingkat keterlibatan publik umumnya menunjukkan tingkat keberpihakan yang diberikan kepada suara publik (Morrison dan Dearden, 2013). Pengembangan teori lebih lanjut menunjukkan bahwa partisipasi adalah pertukaran informasi antara masyarakat dengan pemerintahnya (Tritter dan McCallum, 2006). Namun demikian, fakta menunjukkan bahwa konsultasi masih mendominasi hubungan di antara keduanya, di mana hubungan pertukaran pengetahuan tidak terjalin dengan baik. Partisipasi yang bermakna (meaningful participation) adalah model partisipasi yang mendukung pembentukan hubungan melalui keterlibatan, kolaborasi, atau pemberdayaan masyarakat sedemikian rupa sehingga mereka dapat menyumbangkan pengetahuannya dalam perencanaan pembangunan. 
Sebagaimana Abels (2007) mengatakan bahwa suatu masyarakat dikatakan belum sejahtera jika masyarakat masih mengalami berbagai kekurangan baik secara material maupun spiritual. Karenanya, konsep pemberdayaan (empowerment) dalam wacana pembangunan masyarakat selalu dihubungkan dengan konsep mandiri, partisipasi, jaringan kerja, dan keadilan. Flanagan et al. (2005) mengatakan bahwa pemberdayaan adalah proses pengambilan keputusan oleh orang-orang yang secara konsisten melaksanakan keputusan tersebut. Artinya, bukan pencapaian "tujuan" yang penting, tetapi proses dalam pengambilan keputusan.

Partisipasi merupakan komponen penting dalam membangkitkan kemandirian dan proses pemberdayaan. Partisipasi aktif masyarakat dalam setiap proses pengambilan keputusan merupakan hal terpenting dalam pemberdayaan. Green dan Brock (2005) mengemukakan secara sederhana bahwa partisipasi mengandung makna keterlibatan seseorang atau sekelompok orang dalam suatu kegiatan untuk mencapai sesuatu yang secara sadar diinginkan oleh pihak yang berkepentingan tersebut. Berdasarkan definisi tersebut dapat disimpulkan bahwa partisipasi masyarakat dalam pembangunan memiliki makna (meaningful participation) apabila menyangkut keterlibatan secara aktif dalam pengambilan keputusan, pelaksanaan, dan evaluasi.

Sayangnya, masyarakat memiliki keterbatasan untuk ikut aktif dalam perencanaan pembangunan dimana hal ini tidak mendorong mereka untuk aktif dalam berpartisipasi. Keterbatasan tersebut disebabkan karena dua hal yaitu faktor eksternal dan internal. Faktor eksternal karena pendekatan bottom-up yang diterapkan pemerintah bersifat seremonial dengan tujuan untuk memudahkan pelaksanaan musyawarah perencanaan pembangunan, sehingga keterlibatan masyarakat secara keseluruhan sangat kurang. Sementara, faktor internal adalah keterbatasan dalam diri masyarakat itu sendiri dimana mereka tidak mampu menyampaikan gagasan dengan baik, seperti usulan pembangunan yang tidak layak.
Berdasarkan uraian tersebut, maka tujuan kegiatan ini adalah untuk mendorong upaya keterlibatan masyarakat desa melalui penuangan ide-ide pemikiran mereka secara benar dan baik ke dalam bentuk tulisan sederhana atau proposal pembangunan yang nantinya diajukan dalam musyawarah perencanaan pembangunan (musrenbang) desa. Target pengabdian masyrakat ini adalah agar ide masyarakat sejalan dengan visi dan misi pembangunan pemerintah sehingga ide yang tertuang dalam proposal dapat diterima oleh pemerintah daerah. Luaran pengabdian masyarakat ini adalah proposal kegiatan yang dibangun dari partisipasi aktif masyarakat dalam perencanaan pembangunan.

\section{METODE PELAKSANAAN}

Partisipasi masyarakat dalam proses pembangunan akan terwujud sebagai suatu kegiatan nyata apabila terpenuhi adanya tiga faktor utama yang mendukungnya, yaitu (1) kemauan, (2) kemampuan, dan (3) kesempatan bagi masyarakat untuk berpartisipasi (Bang, 2009). Ketiga faktor tersebut akan dipengaruhi oleh berbagai faktor di seputar kehidupan manusia yang saling berinteraksi satu dengan yang lainnya, seperti psikologis individu (needs, harapan, motif, reward), pendidikan, adanya informasi, keterampilan, teknologi, kelembagaan yang mendukung, struktural dan stratifikasi sosial, budaya lokal serta peraturan dan pelayanan pemerintah. Menurut Innes dan Booher (2010), ada unsur yang mendukung untuk berperilaku tertentu pada diri seseorang (person inner determinants) dan terdapat iklan atau lingkungan (environmental factors) yang memungkinkan terjadinya perilaku tersebut.

Menurut Irvin dan Stansbury (2004), bahwa faktor-faktor yang mampengaruhi tingkat kemauan masyarakat untuk berpartisipasi adalah motif, harapan, needs, reward, dan penguasaan informasi. Faktor yang memberikan kesempatan masyarakat untuk berpartisipasi adalah pengaturan dan pelayanan, kelembagaan, struktur dan stratifikasi sosial, budaya lokal, kepemimpinan, sarana dan prasarana. Sedangkan faktor yang mendorong adalah pendidikan, modal, dan pengalaman yang dimiliki. 
Tiga prinsip dasar dalam menumbuhkan partisipasi masyarakat desa agar ikut serta dalam pembangunan dapat dilakukan dengan cara:

(1) Learning process (learning by doing); proses kegiatan dengan melakukan aktivitas proyek dan sekaligus mengamati, menganalisa kebutuhan dan keinginan masyarakat.

(2) Institusional development; melakukan kegiatan melalui pengembangan pranata sosial yang sudah ada dalam masyarakat. Karena institusi atau pranata sosial masyarakat merupakan daya tampung dan daya dukung sosial.

(3) Participatory; cara ini merupakan suatu pendekatan yang umum dilakukan untuk dapat menggali need yang ada dalam masyarakat.

Sementara, Beyers dan Goossens (2008) menegaskan bahwa bentuk partisipasi masyarakat dalam proses pembangunan terdiri dari 1)participation in decision making; 2) participation in implementation; 3) participation in benefits; dan 4) participation in evaluation. Berkaitan dengan hal tersebut, maka dapat diketahui bahwa partisipasi masyarakat dilakukan mulai dari tahap perencanaan, pelaksanaan, penerimaan, pemanfaatan dan pemeliharaan, pengembangan hasil pembangunan, serta pengawasan dan penilaian terhadap hasil pembangunan.

Lokasi pengabdian masyarakat ini adalah Desa Je'netallasa, yaitu sebuah desa yang merupakan pemekaran dari Desa Kanjilo. Desa ini dimekarkan menjadi dua desa dan satu kelurahan, yaitu Desa Kanjilo sebagai desa induk, kelurahan lembang parang, dan desa persiapan Je'netallasa. Desa Je'netallasa memiliki luas sebesar 3,22 $\mathrm{km}^{2}$ dan terletak 31 km dalam jarak tempuh dari Kabupaten Gowa, di Provinsi Sulawesi Selatan. Desa ini terletak di Kecamatan Pallangga yang berjarak sekitar 5,3 $\mathrm{km}$ dari ibukota kecamatan, adalah merupakan salah satu desa terbaik dari 9 desa di Kabupaten Gowa.

Desa Je'netallasa memiliki 4 dusun dengan total populasi 17.696 jiwa. Sumber mata pencaharian utama masyarakat adalah pertanian. Desa Je'netallasa dipilih untuk berpartisipasi dalam program pengabdian berupa pelatihan masyarakat desa karena desa ini memiliki tingkat pengangguran yang cukup tinggi. Program pelatihan ini merupakan program aplikasi praktis di lokasi lapangan untuk memberikan bantuan kepada masyarakat desa dalam menyampaikan gagasan/ide mereka secara terstruktur pada kegiatan Musrenbang Desa. Masyarakat desa, dalam hal ini para pemuda dan petani, tahu betul tujuan dari pelatihan ini yaitu membantu mereka merumuskan ide mereka dengan baik dan benar agar sesuai atau sinkron dengan rencana pemerintah desa. Hal ini penting agar ide-ide yang mereka sampaikan dapat diakomodir dalam Musrenbang Desa, dan oleh karena itu antusiasme masyarakat untuk berpartisipasi dan bekerja sama dapat meningkat

\section{HASIL DAN PEMBAHASAN \\ Penilaian Kebutuhan}

Tahap pertama kegiatan ini adalah penilaian kebutuhan berdasarkan partisipasi masyarakat. Setelah kegiatan ini selesai dilaksanakan, maka informasi yang dikumpulkan dianalisis dan ditafsirkan. Pengumpulan informasi tersebut dimaksudkan untuk menentukan penyebab dan konsekuensi dari masalah yang telah diidentifikasi dan menghubungkannya dalam hubungan sebabakibat. Semakin baik masalah dipahami, maka semakin baik pula suatu proyek kegiatan dirancang untuk mengatasi permasalahan. Di samping itu, teknik analisis masalah digunakan untuk menginterpretasikan data dan mengidentifikasi hubungan sebab dan akibat permasalahan. Hal-hal yang dipertimbangkan dalam analisis masalah adalah:

Apa yang menjadi suatu permasalahan, serta sebab dan akibat dari permasalahan tersebut?

Dalam hal ini, masalah adalah situasi khusus yang bersifat kurang baik (negatif) terkait dengan kesejahteraan/keamanan seseorang atau kelompok orang. Misalnya, tingkat kematian bayi yang tinggi dari para ibu melahirkan atau peningkatan penyakit diare di kalangan anak balita pada suatu daerah. Keduanya merupakan contoh dari permasalahan.

Sebab/Penyebab adalah faktor-faktor masalah yang ada di rumah tangga, masyarakat, 
organisasi, dan negara yang telah mengidentifikasi atau memformulasikannya sebagai suatu permasalahan. Penyebab dapat dianalisis dalam konteks perilaku, kondisi, pengetahuan, sikap dan praktik. Terdapat dua tingkatan penyebab yaitu penyebab mendasar (underlying causes) dan akar penyebab (rootcauses). Bagian ini menjelaskan pemaknaan dari penyebab mendasar dan akar penyebab sebagai berikut, pertama, penyebab mendasar adalah penyebab yang dapat terlihat dan diingat pertama kali dalam proses analisis masalah. Penyebab mendasari dapat dipertimbangkan dalam berbagai dimensi hubungan sebab dan akibat dari permasalahan. Misalnya, ketika memeriksa penyebab yang mendasari peningkatan angka kematian bayi di kalangan ibu melahirkan, dapat ditarik kesimpulan bahwa ibu melahirkan tidak tertangani secara baik.

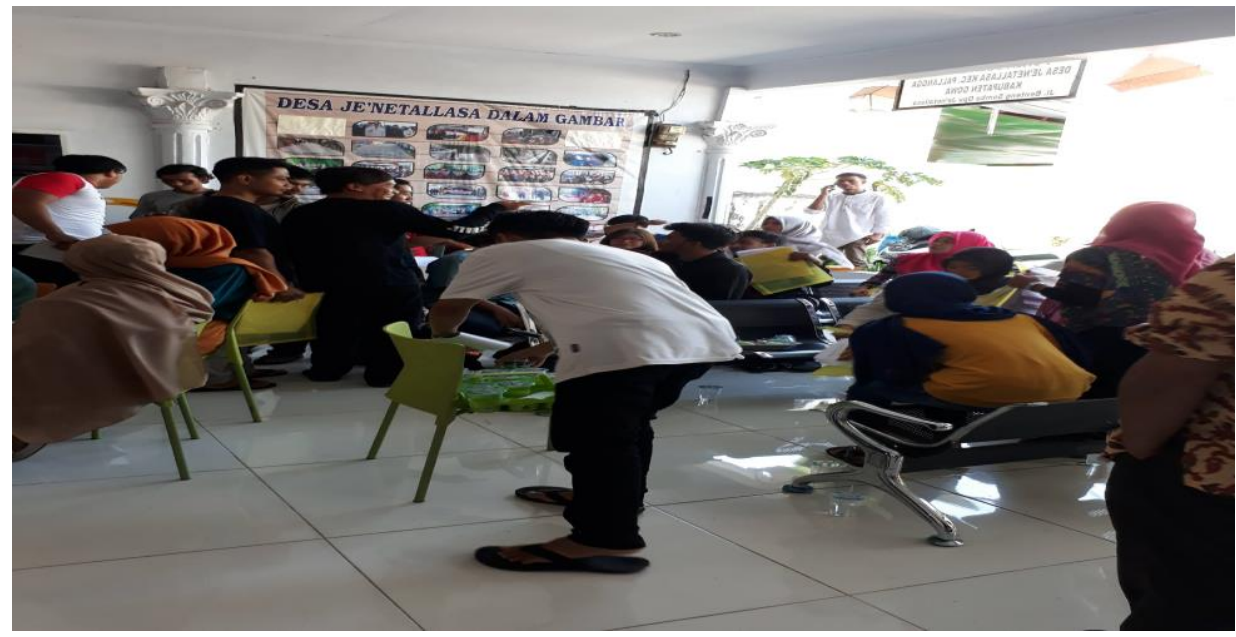

Gambar 1. Diskusi Penilaian kebutuhan

Penyebab yang mendasari fakta ini mungkin karena mereka tidak memiliki akses ke rumah sakit, atau bahwa mereka tidak pernah dididik tentang pentingnya proses kelahiran sehingga terlambat membawa ke rumah sakit, atau bahkan mereka tidak ingin disentuh oleh dokter/tenaga medis. Penyebab yang mendasari dapat dieksplorasi dengan terus bertanya "mengapa permasalahan terjadi", yang pada akhirnya sampai ke pengidentifikasian akar penyebab.

Selanjutnya, dilakukan pemaknaan dari tingkatan berikutnya yaitu akar penyebab. Akar penyebab adalah suatu pengidentifikasian masalah dengan menganalisisnya sampai ke inti permasalahan. Akar penyebab memberikan penjelasan akhir dari suatu permasalahan yang terjadi. Misalnya, akar penyebab dari tingginya angka kematian bayi di kalangan ibu melahirkan di negara tertentu bisa menjadi norma budaya yang kuat yang memandang penanganan ibu melahirkan oleh dokter/tenaga medis sebagai hal yang tabu. Akar penyebab sering tertanam dalam norma-norma budaya pada masyarakat, dan sulit untuk diatasi. Oleh karenanya, fokus penyelesaian masalah harus berkonsentrasi pada penyebab yang mendasarinya

Akibat/Konsekuensi adalah suatu kondisi sosial, lingkungan, politik atau ekonomi yang dihasilkan dari adanya permasalahan. Sebagai contoh, beberapa konsekuensi dari tingginya tingkat kematian bayi di kalangan ibu melahirkan adalah meningkatnya angka kesakitan dan kematian ibu, rendahnya angka harapan hidup, atau rendahnya angka angkatan kerja di kalangan kaum muda.

\section{Langkah dalam analisis masalah}

Setelah mengetahui sebab dan akibat dari suatu masalah, maka langkah selanjutnya adalah melakukan analisis masalah. Salah satu cara untuk memikirkan langkah-langkah logis dalam mengidentifikasi penyebab masalah adalah dengan mengajukan pertanyaan "mengapa?" Dalam menjawab pertanyaan ini, tim desain dari 
proyek kegiatan secara struktur logika bergerak ke bawah menuju

penyebab yang mendasari permasalahan. Kemungkinan besar terdapat lebih dari satu penyebab mendasar. Ketika tim desain sampai pada titik di mana sulit untuk menemukan jawaban baru atas permasalahan yang ada, hal ini berarti bahwa sebagian besar penyebab mendasar dan akar permasalahan telah diidentifikasi dan tiba saatnya untuk merancang proyek kegiatan. Atau dengan kata lain "mengapa" yang dipertanyakan dari suatu masalah telah ditemukan jawabannya. Metode "mengapa" ini mudah digunakan dan dapat dipahami oleh kelompok masyarakat mana pun.

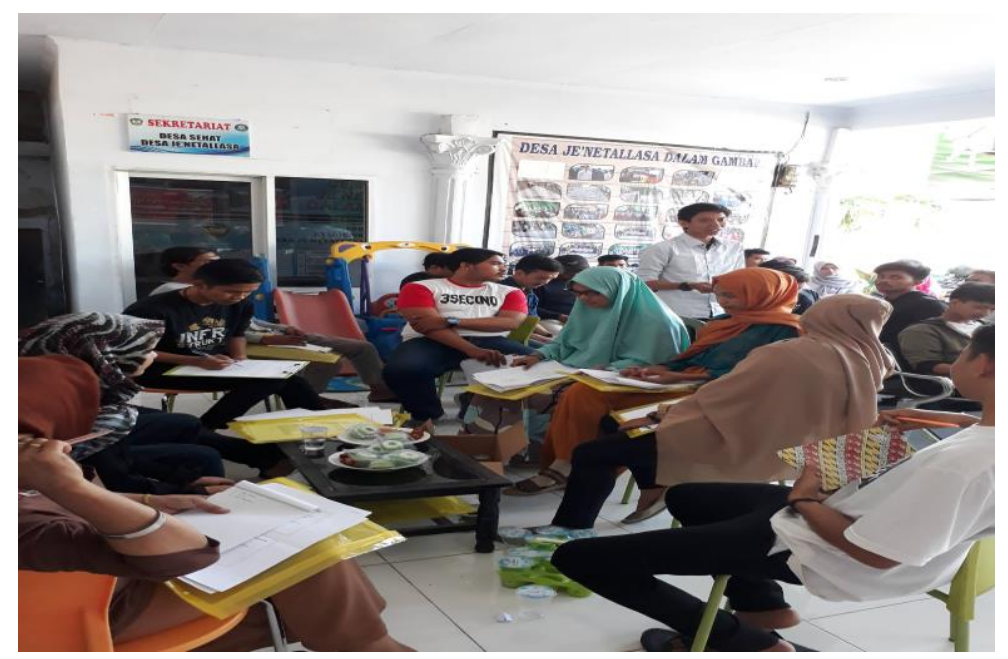

Gambar 2. Diskusi Pemetaan Masalah

Untuk memvisualisasikan masalah, berbagai teknik dapat digunakan seperti diagram Pohon Masalah (Problem Tree Diagram), diagram Tulang Ikan (Fish Bone Diagram), atau Diagram Cascade (Brock dan Columbia, 2007)). Salah satu yang umum digunakan untuk menganalisis masalah adalah pengembangan pohon masalah. Setelah masalah dipahami dari setiap lapisan, maka menjadi jelas bagaimana merancang intervensi dari proyek kegiatan agar perubahan positif dapat dilakukan. Saat menganalisis dan menafsirkan penyebab, ada beberapa pertanyaan yang harus diajukan: Apakah masing-masing sebab dan akibat itu logis? Dapatkah penyebab diidentifikasi pada setiap tingkatan dalam hierarki analisis masalah? Jika tidak, mengapa? Apa kontribusi atau signifikansi dari setiap aliran sebab-akibat terhadap permasalahan? Apakah ada penyebab yang berulang?

\section{Analisis Pemangku Kepentingan}

Selanjutnya dilakukan analisis pemangku kepentigan. Analisis pemangku kepentingan adalah pemetaan semua pihak baik perorangan, kelompok, maupun organisasi yang tertarik atau terlibat dengan isu permasalahan yang akan ditangani oleh kelompok desain proyek kegiatan. Pemangku kepentingan memiliki cakupan yang luas dan seringkali sulit untuk mengidentifikasi kelompok tersebut sepenuhnya. Namun demikian, pemangku kepentingan utama harus diidentifikasi pada awal desain proyek kegiatan. Mereka dapat mencakup para pemangku kepentingan yang ada dari program kegiatan yang sedang berjalan, kaum muda, tokoh masyarakat dan agama, politisi, guru, penyedia layanan, pengusaha, usaha kecil, LSM, organisasi dan lembaga pemerintah, serta kelompok lainnya.

Analisis pemangku kepentingan secara menyeluruh pada awal desain proyek kegiatan adalah suatu tindakan yang penting dalam rangka mendapatkan informasi sebanyak mungkin terkait dengan kegiatan yang dilakukan dan permasalahan yang kemungkinan muncul. Informasi tersebut dibutuhkan untuk mengetahui pemahaman tentang organisasi atau kelompok orang yang memiliki minat dengan permasalahan yang akan ditangani, apa minat mereka, apakah 
tujuan mereka sama dengan tujuan tim, dapatkah mereka membantu proyek kegiatan dan dengan cara seperti apa, siapa yang dapat memiliki pengaruh negatif dan menjadi penghalang bagi proyek, serta bagaimana proses perencanaan informasi ini dapat dimanfaatkan. Demikianlah informasi yang dikumpulkan saat tim desain proyek kegiatan menganalisis pemangku kepentingan. Pemangku kepentingan ini dapat berubah selama proyek berjalan, oleh karenanya analisis pemangku kepentingan pun mengalami pembaharuan apabila diperlukan, namun pada tahap selanjutnya dari implementasi proyek. Pada saat melakukan analisis pemangku kepentingan, peserta memperhatikan beberap hal yang tertuang dalam tabel 1 sebagai berikut:

Tabel 1 Analisis kepentingan

\begin{tabular}{|c|c|}
\hline Isu & Pertimbangan \\
\hline Kepentingan & $\begin{array}{l}\text { Poin ini mengacu pada kepentingan pemangku kepentingan dalam proyek } \\
\text { kegiatan (tergantung pada masalahnya). Jika pemangku kepentingan terlibat } \\
\text { langsung dalam kegiatan yang berkaitan dengan kegiatan program, maka } \\
\text { minatnya adalah yang utama, jika tidak maka kepentingannya adalah yang } \\
\text { kedua }\end{array}$ \\
\hline Tingkat pengetahuan & $\begin{array}{l}\text { Hal ini mencakup tingkat pengetahuan para pemangku kepentingan tentang } \\
\text { bidang dan isu-isu dari proyek kegiatan. Pemangku kepentingan yang } \\
\text { merupakan pihak internal sistem akan lebih mengetahui tentang permasalahan } \\
\text { proyek kegiatan ini }\end{array}$ \\
\hline Sumberdaya yang tersedia & $\begin{array}{l}\text { Identifikasi sumber daya yang dimiliki atau dapat diakses oleh pemangku } \\
\text { kepentingan, seperti sumber daya manusia, waktu, sumber daya keuangan dan } \\
\text { hukum, teknologi, dan informasi umum }\end{array}$ \\
\hline $\begin{array}{l}\text { Pendukung (pro) / lawan } \\
\text { (kontra): }\end{array}$ & $\begin{array}{l}\text { Area ini mengacu pada pemangku kepentingan yang mendukung misi dari } \\
\text { proyek kegiatan yang akan dilakukan dan dapat membantu memenuhi } \\
\text { tujuannya. Lawan adalah pemangku kepentingan yang tidak mendukung tujuan } \\
\text { proyek dan dapat menghambat keberhasilannya. Tim dari proyek kegiatan } \\
\text { harus mendefinisikan para pemangku kepentingan baik sebagai lawan ataupun } \\
\text { pendukung berdasarkan pengetahuan dan pemahaman terbaik mereka }\end{array}$ \\
\hline Pengaruh / Kewenangan & $\begin{array}{l}\text { Poin ini menentukan tingkat kewenangan yang dimiliki oleh pemangku } \\
\text { kepentingan untuk melakukan perubahan dan membuat keputusan akhir terkait } \\
\text { dengan proyek kegiatan }\end{array}$ \\
\hline Prioritas & $\begin{array}{l}\text { Hal ini mengindikasikan tingkat kekhawatiran yang dimiliki oleh pemangku } \\
\text { kepentingan terhadap proyek yang akan dilaksanakan }\end{array}$ \\
\hline
\end{tabular}

Setelah memahami posisi para pemangku kepentingan, maka tim desain proyek kegiatan mengurangi risiko permasalahan yang mungkin dapat muncul pada saat implementasi proyek. Selain itu, pengetahuan tentang situasi para pemangku kepentingan juga membantu tim untuk membangun kemitraan strategis dan memahami risiko yang mungkin dialami atas inisiasi dan implementasi proyek kegiatan.

Langkah selanjutnya yang perlu dilakukan oleh tim desain proyek setelah melakukan analisis situasi yang meliputi analisis data dan penilaian kebutuhan, analisis masalah, dan analisis pemangku kepentingan adalah pembuatan usulan (proposal) program untuk diajukan kepada pemerintah. Proposal yang diajukan ini haruslah sejalan dengan visi dan misi pemerintah daerah yang akan diulas pada pembahasan berikut.

\section{Penyusunan usulan Proyek}

Langkah berikutnya adalah penyusunan proposal, dalam hal ini proposal yang menawarkan rencana kegiatan untuk memenuhi suatu kebutuhan. Kebutuhan yang dimaksud adalah kebutuhan bersama yang diperoleh melalui analisis data dan penilaian kebutuhan. Di samping itu, kebutuhan tersebut harus sejalan dengan visi misi daerah. Pembaca Anda akan mengevaluasi usulan rencana Anda sesuai dengan narasi yang dituangkan secara tertulis dalam menjawab beberapa pertanyaan 
penting yang perlu diketahui pembaca. Semakin peluang usulan diterima. baik Anda menuliskannya maka semakin besar

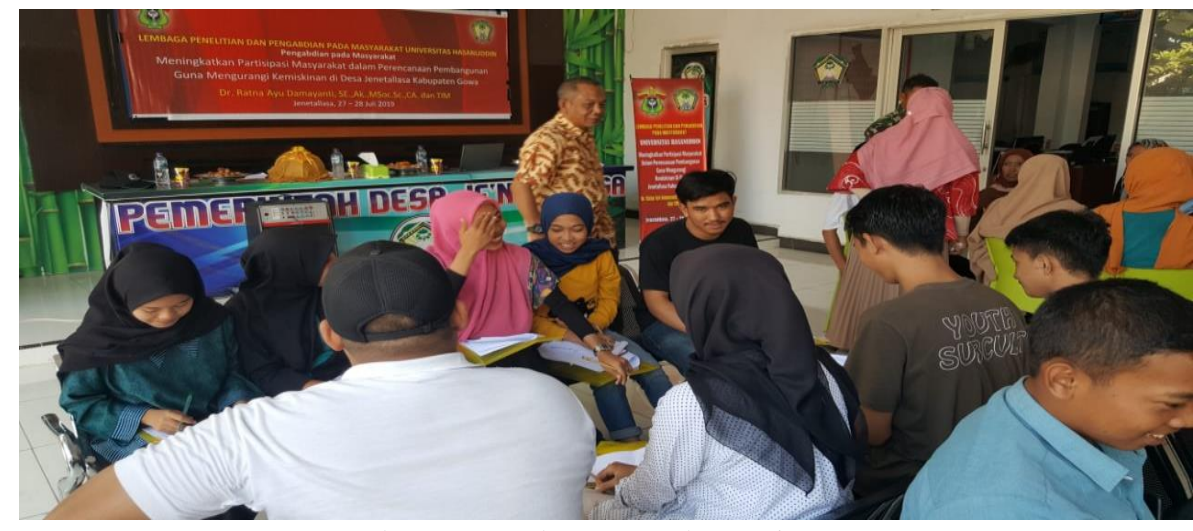

Gambar 3. Usulan Proyek Kegiatan

Menurut beberapa literatur baik buku teks maupun secara on-line menyatakan bahwa terdapat beberapa faktor penting yang perlu dipertimbangkan dalam panduan format penulisan usulan proyek kegiatan. Namun demikian, format yang paling fleksibel dan mendapat penerimaan secara luas dari faktorfaktor penting tersebut adalah pemilihan topik kegiatan, judul dari kegiatan, masalah, output dan dampak yang dihasilkan dari output tersebut, pendekatan yang digunakan dan aktivitasnya, lokasi proyek kegiatan, mitra kerja, dan terakhir adalah kebutuhan anggaran. Kesemua faktorfaktor ini perlu diuraikan dalam proposal dengan baik dan jelas. Faktor-faktor penting yang perlu diperhatikan dalam tahapan pembuatan usulan kegiatan tersebut adalah tertuang dalam tabel 2:

Tabel 2: Tahapan kegiatan penyusunan proposal

\begin{tabular}{|l|l|}
\hline \multicolumn{1}{|c|}{ Isu } & \multicolumn{1}{c|}{ Pertimbangan } \\
\hline $\begin{array}{l}\text { Pemilihan } \\
\text { kegiatan }\end{array}$ & $\begin{array}{l}\text { Pemilihan topik kegiatan dalam penulisan proposal disesuaikan dengan prioritas } \\
\text { penyandang dana yang dalam hal ini adalah pemerintah daerah. Sebagian besar } \\
\text { pemerintah daerah telah menguraikan bidang-bidang prioritas yang akan mereka } \\
\text { lakukan dimana prioritas ini sejalan dengan visi misi daerah. Berdasarkan prioritas } \\
\text { yang ada, maka peserta melaksanakan pengamatan secara menyeluruh untuk } \\
\text { mengidentifikasi bidang-bidang prioritas yang sesuai dengan permasalahan di } \\
\text { sekitar. }\end{array}$ \\
\hline Judul Kegiatan & $\begin{array}{l}\text { Pada saat membuat proposal (usulan) kegiatan, maka judul kegiatan disusun } \\
\text { dengan rapi dan mencakup hal-hal sebagai berikut: (1) Judul proyek kegiatan; (2) } \\
\text { Nama orang / tim pengusul; (3) Nama pembina / mitra; (4) Tanggal penyerahan } \\
\text { usulan proyek. Selain itu, judul kegiatan terlihat professional, rapi, dan menarik } \\
\text { perhatian pembaca. }\end{array}$ \\
\hline $\begin{array}{l}\text { Pendekatan } \\
\text { kegiatan }\end{array}$ & $\begin{array}{l}\text { Selanjutnya dibuatlah pendekatan yang digunakan untuk melaksanakan proyek } \\
\text { usulan. Artinya, dalam hal ini, menunjukkan langkah-langkah atau cara yang akan } \\
\text { digunakan untuk melaksanakan proyek kegiatan sehinga mendapatkan hasil yang } \\
\text { bermanfaat baik bagi pemangku kepentingan yang terlibat maupun bagi orang lain } \\
\text { di luar proyek. }\end{array}$ \\
\hline $\begin{array}{l}\text { Dampak dan penerima } \\
\text { manfaat }\end{array}$ & $\begin{array}{l}\text { Pada poin ini dijelaskan siapa yang mendapatkan manfaat dari proyek, kapan, dan } \\
\text { bagaimana. Di samping itu, dijelaskan bagaimana output proyek disebarluaskan } \\
\text { kepada penerima manfaat sasaran. }\end{array}$ \\
\hline Lokasi proyek & $\begin{array}{l}\text { Peserta menunjukkan di mana proyek akan dilaksanakan misalnya wilayah, area, } \\
\text { desa, dan lainnya. Dalam hal ini, usulan perlu mempertimbangkan untuk } \\
\text { menyediakan peta lokasi dari proyek kegiatan tersebut }\end{array}$ \\
\hline Anggaran & Menentukan anggaran kegiatan, dengan mempertimbangkan bahwa anggaran \\
\hline
\end{tabular}




\begin{tabular}{|l|l|}
\hline Isu & \multicolumn{1}{|c|}{ Pertimbangan } \\
\hline & pemerintah jumlahnya terbatas sementara banyak kegiatan yang akan dibiayai. \\
& $\begin{array}{l}\text { Oleh karena itu, peserta menghitung dengan baik berapa total anggaran yang } \\
\text { dibutuhkan dan kegiatan apa yang dibiayai oleh pemerintah. Jadikan anggaran } \\
\text { Anda realistis, karena perlu untuk dipertimbangkan oleh pengambil kebijakan }\end{array}$ \\
\hline
\end{tabular}

Tahapan tersebut di atas dilakukan dengan metode partisipatif dimana tim pengabdian hanya menjadi fasilitator dan masyarakat menjadi kunci dari kegiatan tersebut.

\section{KESIMPULAN DAN SARAN}

Masyarakat penerima program perlu memahami permasalahan terkait identifikasi masalah pembangunan dan proses perencanaan program pembangunan agar keterlibatan mereka dalam musrenbang semakin meningkat. Pengabdian pada masyarakat ini memberikan pelatihan kepada masyarakat desa khususnya kaum pemuda sehingga mereka dapat menganalisis situasi permasalahan desa yang mereka miliki. Pelatihan memungkinkan peserta pelatihan membuat skala prioritas yang disinkronkan dengan perencanaan desa, untuk kemudian dituangkan ke dalam bentuk proposal yang baik dan tepat sasaran.

Saran pengabdian ini adalah saat menganalisis situasi dalam rangka mengenali permasalahan desa secara detail, perlu dilakukan dengan melibatkan semua pemangku kepentingan. Bentuk pembuatan proposal yang baik sangat diperlukan oleh masyarakat desa agar supaya usulan mereka dalam kegiatan Musrenbang Desa dapat dipertimbangkan.

\section{DAFTAR PUSTAKA}

Abels, G. (2007). Citizen involvement in public policy-making: does it improve democratic legitimacy and accountability? the case of pTA. Interdisciplinary Information Sciences, 1, 103 - 116.

Beyers, W., \& Goossens, L. (2008). Dynamics of perceived parenting and identity formation in late adolescence. Journal of Adolescence, 31, 165 - 184.

Flanagan, C.A., Gallay, L.S., Gill, S., Gallay, E., \& Nri, N. (2005). What does democracy mean? Correlates of adolescents' views.
Journal of Adolescent Research, 20, 193 218.

Green, M.C., \& Brock, T.C. (2005). Organizational membership versus informal interaction: contributions to skills and perceptions that build social capital. Political Psychology, 26 (1), 1 - 25.

Hansen, D.M., Larson, R.W., \& Dworkin, J.B. (2005). What adolescents learn in organized youth activities: a survey of self-reported developmental experiences. Journal of Research on Adolescence, 13 (1), $25-55$.

Innes, J., \& Booher, D. (2010). Planning with Complexity: An Introduction to Collaborative Rationality for Public Policy. London: Routledge.

Irvin, R.A., \& Stansbury, J. (2004). Citizen participation in decision making: is it worth the effort? Public Administration Review, 64 (1), 55 - 65.

Larson, R.W., Hansen, D.M., \& Moneta, G. (2006). Differing profiles of developmental experiences across types of organized youth activities. Developmental Psychology, 42 (5), 849 - 863.

Morrison, C., \& Dearden, A. (2013). Beyond tokenistic participation: Using representational artefacts to enable meaningful public participation in healthservice design. Health Policy, 112, $179-186$.

Reed, M., (2008). Stakeholder participation for environmental management: a literature review. Biological Conservation, 141, $2417-2431$.

Tritter, J.Q., \& McCallum A. (2006). The snakes and ladders of user involvement: moving beyond Arnstein. Health Policy, 76, 156 68. 